\title{
Isoetes pedersenii, a new species from Southern South America
}

\author{
CECILIA MACLUF ${ }^{1}$, ESTEBAN I. MEZA TORRES ${ }^{2}$ and STELLA M. SOLÍS ${ }^{2}$ \\ ${ }^{1}$ Cátedras de Morfología Vegetal y Palinología, Facultad de Ciencias Naturales y Museo \\ UNLP, Paseo del Bosque s/n, 1900, La Plata, Argentina \\ ${ }^{2}$ Cátedra de Morfología Vegetal, Facultad de Ciencias Exactas y Naturales y Agrimensura \\ Instituto de Botánica del Nordeste (UNNE-CONICET), Av. Libertad 5470, Corrientes, Argentina \\ Manuscript received on November 26, 2008; accepted for publication on September 28, 2009
}

\begin{abstract}
The name Isoetes pedersenii H.P. Fuchs (Lycophyta), a species known only from the Mburucuyá National Park, Corrientes, Argentina, is validated. Observations were carried out on herbarium material with stereoscopic, light and scanning electron microscopes. The species is described and typified. A diagnosis and discussion about its distribution and its relationship with the morphology of other species of Isoetes are provided.
\end{abstract}

Key words: Argentina, Corrientes, Isoetes, Lycophyta, new species.

\section{INTRODUCTION}

The Isoetaceae constitutes a family with a wide distribution. The representatives of this family live from subartic to warm regions in all continents from sea level to approximately 4,500 high. Isoetes L. has about 350 species (Hickey et al. 2003), of which seven species were reported by Ponce (1996) as growing in Argentina. They occur in the provinces of Buenos Aires, Formosa, Córdoba, Tucumán, and in the Patagonian region. Later, Macluf and Ponce (2008) updated the occurrence of Isoetes in Argentina.

The two farms that constitute the Mburucuyá National Park belonged to the botanist Dr. Honoris Causa Troels Myndel Pedersen, who donated these farms in order to create a national park. For 50 years Pedersen was an assiduous collector who formed a herbarium with approximately 30,000 specimens (Arbo 2004). The duplicates of his collections were distributed to the following herbaria: A, B, BR, C, CTES, K, L, LP, MBM, MO, NY, $\mathrm{P}, \mathrm{S}, \mathrm{SI}, \mathrm{U}, \mathrm{US}$, and his collections are cited like this in many taxonomic revisions (Krapovickas 2000). These

Correspondence to: Cecilia Macluf

E-mail: ccmacluf@aol.com; ccmacluf@hotmail.com collections gave to this park an added botanical value, since many of Pedersen's specimens were recognized as types for many new species (Arbo 2004).

During the development of the Project "Flórula del Parque Nacional Mburucuyá", subproject "Flórula Pteridophytica", several nomenclatural problems became evident for the treatment of taxa in that national park. One of the nomenclatural problems concerns Isoetes pedersenii, which was effectively published for the first time by H.P. Fuchs-Eckert (1982) and later accepted by Macluf et al. (2006a, b). However, in none of the publications it was published with a latin diagnosis as specified in articles 32.1 of the International Code of Botanical Nomenclature of Vienna (Mc Neill et al. 2007). FuchsEckert (1982) mentioned the existence of a holotype housed in the Herbarium of Paris (P), which was collected in Corrientes, Argentina. The data supplied in the publication is mentioned below:

"Isoetes pedersenii (H.P. Fuchs, in sched. Rev., in hb P (24 December 1980) ined.) Argentina (Prov. Corrientes) Holotypus: $\mathbf{P}$

(= Isoëtes gardneriana, sensu Tr. M. Pedersen, in sched n. 8105, non (G. Kunze, in sched. 
ex) METTENIUS 1859, Fil. Lechl. (2): 36, in textu (Januar 1859), nomen seminudum, ex) A. Braun 1862, in Verhn. Bot. Ver. Prov. Brandenbeg."

R.J. Hickey (1985), in his unpublished thesis, updated the neotropical species of Isoetes, and provided an English description of Isoetes pedersenii. Later, Macluf et al. (2006a, b) performed an analysis with electron microscopy of the microspores of all the species of Southern South America, among which I. pedersenii was included. Additional background information on this name was documented in correspondence dated XI.30.1981 sent by Fuchs to Pedersen, which is kept in the Library of the Botany Institute of the Northeast (IBONE). A list of specimens collected by Pedersen and determined by Fuchs was provided in this letter. In the detail of a specimen, the following is specified:

"T.M. Pedersen, no. 8105: Isoetes pedersenii H.P. FUCHS, in sched., ined. (TYPUS).”

As part of the study of the Isoetoids that grow in Southern South America and within the boundaries of the Project "Florula of the National Park Mburucuyá", the name used by Fuchs-Eckert (1982), R.J. Hickey, unpublished data and Macluf et al. (2006a, b), Isoetes pedersenii, is described, typified and validated in accordance with the standards imposed by the International Code of Botanical Nomenclature.

\section{MATERIALS AND METHODS}

Studies were performed on herbarium material borrowed from several herbaria, which are abbreviated in accordance with Holmgren et al. (1990). The material was recovered by warming it in distillated water with some drops of non-ionized detergent. Permanent preparations were made for the anatomical descriptions. This material was dehydrated in an ascending series of tertiary butylic alcohol and was introduced into paraffin (Johansen 1940); transverse sections were made with a rotary microtome at $12-15 \mu \mathrm{m}$. These were dyed with saffranine-astra blue (Luque et al. 1996) and were mounted in Canada balsam.

Observations and photographs were taken with a Leica DM LB2 light microscope (LM), with a digital camera included an Olympus CO11 stereoscopic microscope dissectins scope. Illustrations of features were carried out with a Wild M5 stereoscopic microscope and an Olympus BX 50F binocular microscope. For studies with SEM, the spores were handled with moist brushes without any chemical treatment and placed on doublestick tape on bronze stubs. The samples were coated with gold and examined under a Jeol JSM-35 CF microscope at the SEM laboratory of the Facultad de Ciencias Naturales y Museo, Universidad Nacional de La Plata, La Plata, Argentina.

Megaspore morphology follows the terminology proposed in Tryon and Lugardon (1991).

\section{RESULTS}

Isoetes pedersenii H.P. Fuchs ex Meza T. and Macluf, spec. nov. (Figs. 1-4).

Cormus erectus, bi e trilobatus, $18 \mathrm{~mm}$ latus, $11 \mathrm{~mm}$ elatus; radices dichotomae. Folia 70-80, erecta, 12$30 \mathrm{~cm}$ longa, 4-6 mm basi lata, 1-6 mm lata; alae hyaline et membranaceae, $3 \mathrm{~mm}$ basi latae, $2 \mathrm{~mm}$ medio latae, $10-25 \mathrm{~cm}$ longae (50\% per folia longitudinem ascendentes); fasciculi fibrosi praesentia; subula triquetrus, atroviridis; stomata praesentia; squamae phyllopodia absentia. Sporangium ellipticum usque circulare, hyalinum, 5-6 mm longum, 3 mm latum, basale. Velum incompletum, revolutus versus is apex. Ligula deltata, auriculata, $1.3 \mathrm{~mm}$ longa, $1.85 \mathrm{~mm}$ lata. Labium inconspicuum usque absens. Megaspores, 395-411 $\mu \mathrm{m}$ diametro, verrucosae, verrucae 21.3-43.4 $\mu$ m diametro; zona non dis-

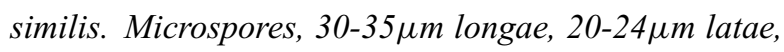
echinatae.

Holotypus: Argentina, Corrientes province: Dep. Mburucuyá, Estancia Santa María, low generally flooded land, 18 March 1967, Pedersen 8105 (CTES); Isotypi: A, C, LP, P, S.

Etymology: The species was dedicated by Fuchs to Dr. T.M. Pedersen, collector and expert of the flora from Corrientes who collected the type specimen.

Corm erect, 2 to 3 lobed, $18 \mathrm{~mm}$ wide, $11 \mathrm{~mm}$ high; roots dichotomously branched. Leaves $70-80$, erect, $12-$ $30 \mathrm{~cm}$ long., 4-6 mm wide at the base, 1-6 $\mathrm{mm}$ wide at the apical length; alae hyaline, membranaceous, $3 \mathrm{~mm}$ wide at the sporangium region, $2 \mathrm{~mm}$ at mid-length, 10 


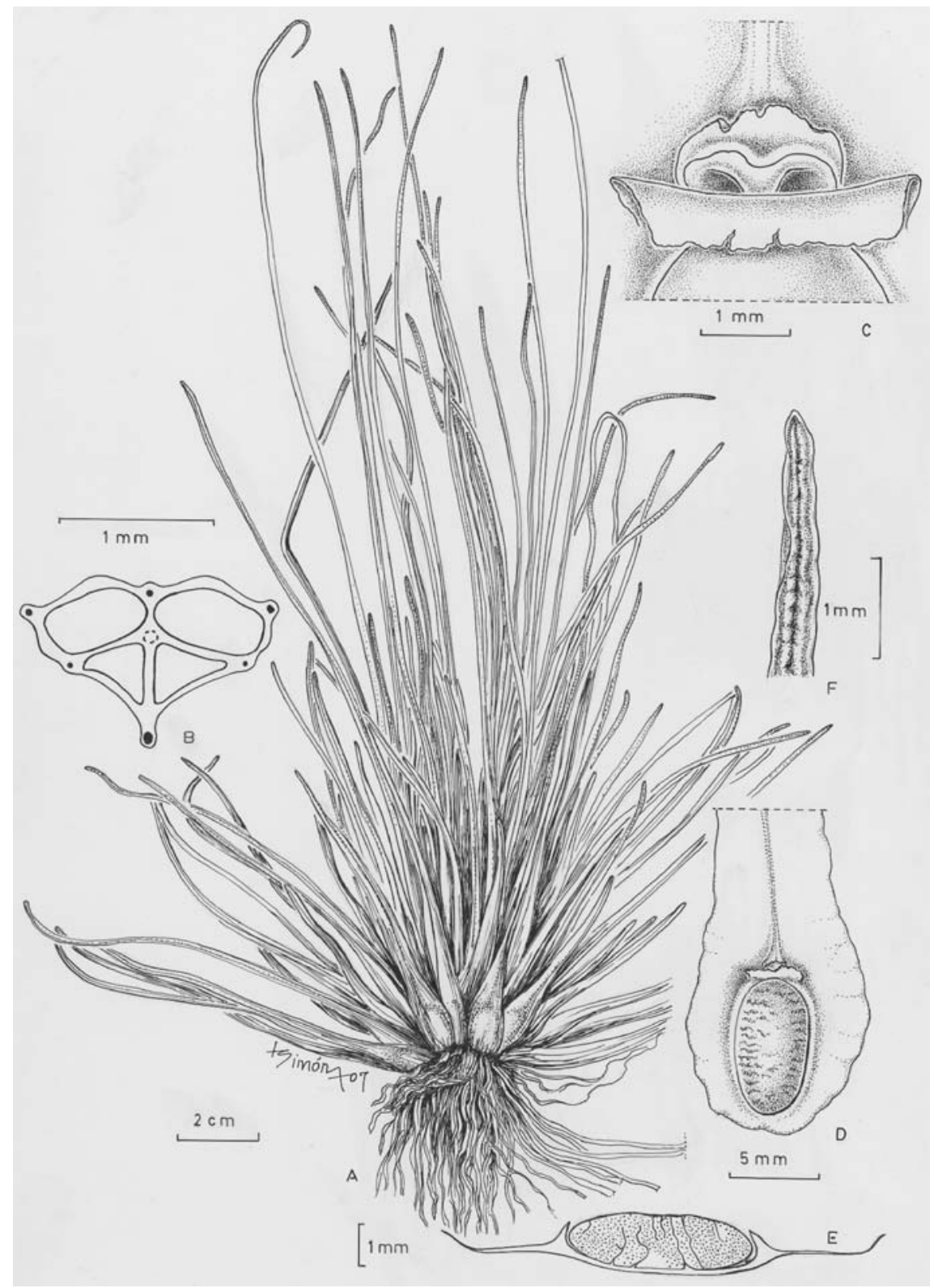

Fig. 1 - Isoetes pedersenii. A - Plant habit. B - Cross section of the subula (terminal region of a microphyll), with 4 air chambers, fiber bundles (black circles) and vascular tissue (cut line). C - Detail of the labium folded in order to let the ligule remnant be seen. D - Basal portion of a microphyll with megasporangium. E - Cross section of microsporangium, with trabeculae arranged transversely. F - Detail of the subula apex. (Pedersen 8105, CTES).

to $25 \mathrm{~cm}$ long (extending until $85 \%$ of the leaf length); fibrous bundles present; subula triquete, dark green (Fig. 1, F); stomata present; scales and phyllopodia absent. Sporangium elliptic to oval, hyaline, 5-8 $\mathrm{mm}$ long, 3-5 mm wide, basal (Fig. 4, A-B). Velum absent. Ligule deltoid, auriculate at base, $1.3 \mathrm{~mm}$ high, $1.85-2 \mathrm{~mm}$ wide. Labium conspicuous, 3-3.5 × 1-1.5 mm (Fig. 1, C). Megaspores subtriangular, trilete, 395 to $411 \mu \mathrm{m}$ in equatorial diameter, verrucate; verrucae 21.3 to $43.4 \mu \mathrm{m}$ diameter; girdle undifferentiated (Fig. 2). Microspores elliptic, monolete, 30-35 $\mu \mathrm{m}$ long, $20-24 \mu \mathrm{m}$ wide, echinate (Fig. 3). 


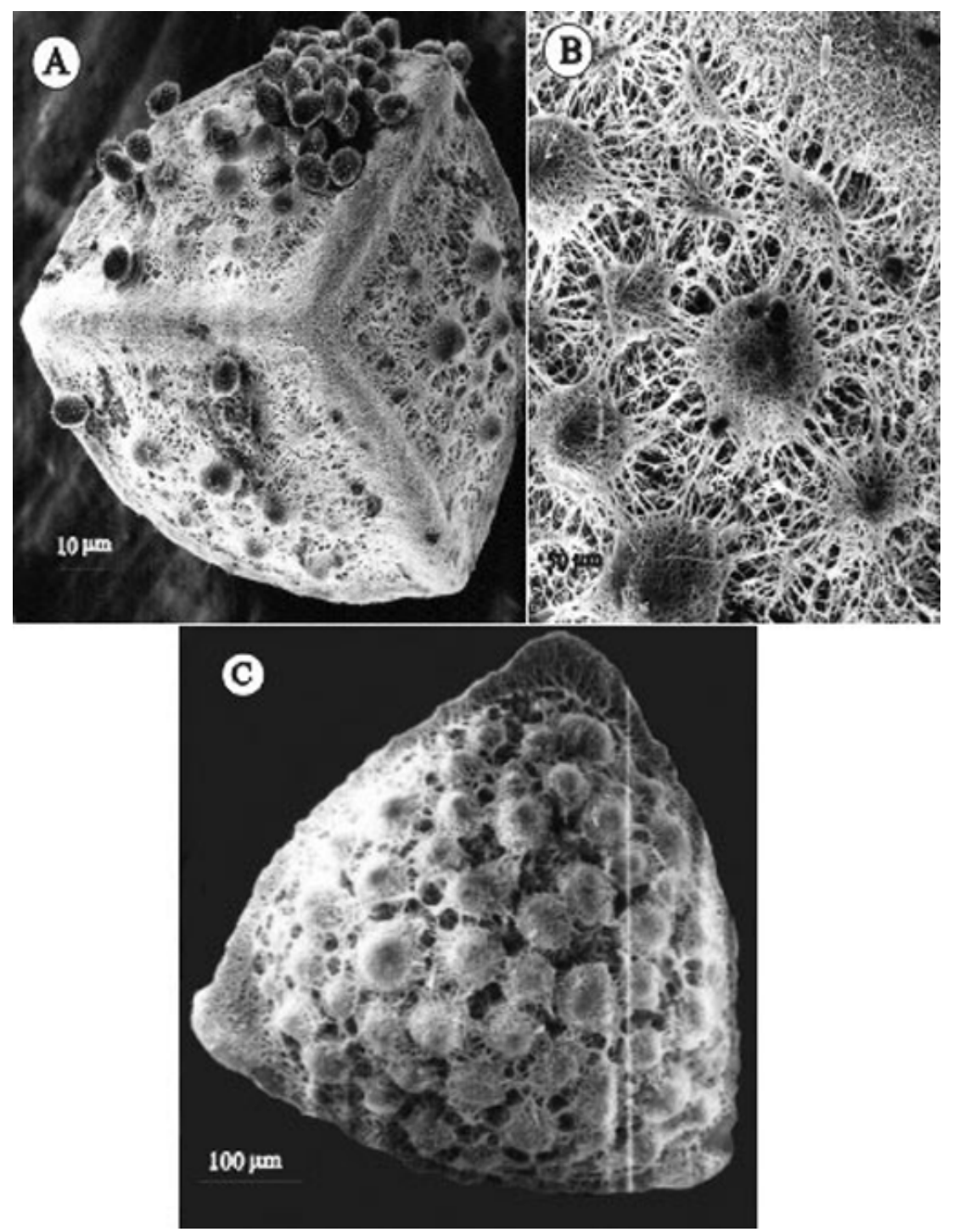

Fig. 2 - Isoetes pedersenii. A-C. Megaspores observed with SEM. A - Proximal view. The laesurae join in the equatorial zone or cingulum. Microspores are observed on the megaspore surface. B - Detail of the proximal structure showing tubercles of different diameter. C - Distal View. (Pedersen 8105, LP).

Isoetes pedersenii perhaps is endemic of Argentina, and is known only from the type collection made in Mburucuyá National Park, Corrientes. It grows in flooded land; the presence of stomates and fibrous bundles and the absence of scale leaves suggest an amphibious habit. Isoetes pedersenii is probably to be also found in the adjacent regions of Argentina, Paraguay and Brazil.

Isoetes pedersenii is distinguished from other species by its megaspores and microspores, and to the type of subula (microphyl tip). Morphologically, it is similar to Isoetes panamensis Maxon and C.V. Morton and to Isoetes gardneriana A. Braun, from which it is differentiated mainly by the megaspore ornamentation. Isoetes panamensis has cones on the megaspore surface, whereas in I. gardneriana the megaspores have tubercles.

\section{OBSERVATIONS}

In the microphyll of Isoetes pedersenii, the supporting tissue consists of six strands, three adaxially, two lat- 


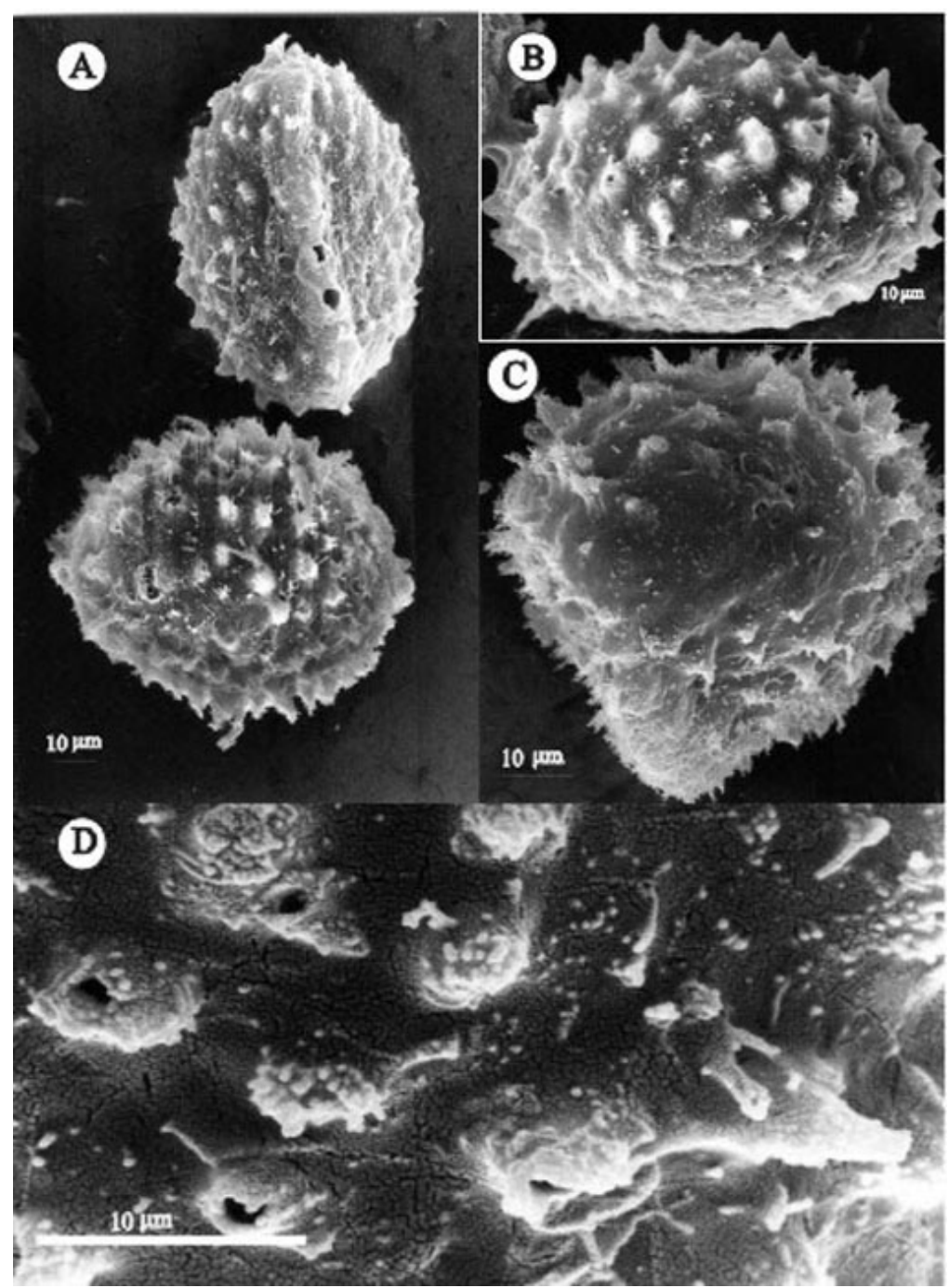

Fig. 3 - Isoetes pedersenii. A-D. Microspores observed with SEM. A - Proximal view (top) and equatorial view (bottom). B - Major equatorial view showing the echinate-tuberculate ornamentation. The echinae are higher and more densely distributed distally. C - Lower equatorial view showing the supra-laesural expansion (Macluf et al. 2006a). D - Detail of the equatorial surface. The ornamentation consists of cones distributed in the entire surface. Some cones show their apex broken. (Pedersen 8105, LP).

eral, and one abaxially, with strongly lignified thick walls and reduced lumen, immersed in a subepidermal (tissue) parenchyma (Fig. 1, B, Fig. 4, C). The presence or absence of peripheral fibers, number and location of Isoetes have been considered to be a diagnostic feature by many authors (Pfeiffer 1922, Parker 1943, Takamiya et al. 1997, Prada and Rolleri 2003), but not by other authors such as Hall (1971) and Kott and Brit- ton (1985). The presence of this tissue would seem to be related to the habitat (Pfeiffer 1922, Takamiya et al. 1997). The aquatic species lack, mechanical support tissue and, in terrestrial and amphibious species, it is well developed. This cannot be completely confirmed since in some aquatic species, such as Isoetes echinospora Durieu, rarely distributed fibers have been observed in the mesophyll (Prada 1979). 


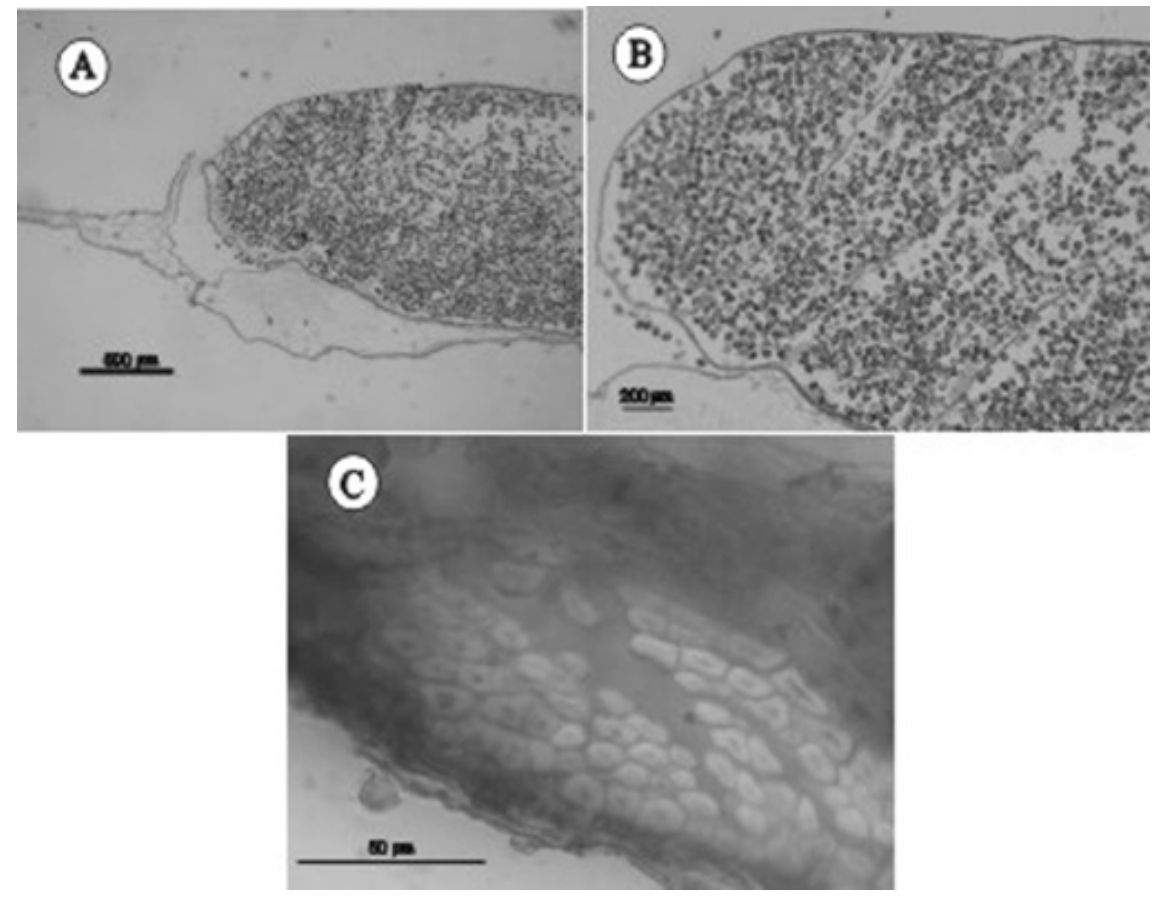

Fig. 4 - Isoetes pedersenii. A-C. Cross sections observed with LM. A - Cross section of the microsporangium, with microspores inside. $\mathrm{B}$ - Detail of the microsporangium where trabeculae can be seen. C - Micrograph of the sclerenchymatic beads of the microphyll. (Pedersen 8105, CTES).

\section{ACKNOWLEDGMENTS}

The authors thank Eng. A. Krapovickas for his critical reading; Rafael Urrejola from the Scanning Electronic Microscopy Service of the "Museo de Ciencias Naturales de La Plata"; Laura Simón for the illustrations; and the reviewers for useful comments on the manuscript. This work was supported by the grant from the National Council of Scientific and Technological Research (CONICET) PIP 5044, and the National Agency of Scientific and Technological Promotion (ANPC y T) PICT 12.758.

\section{RESUMO}

O nome Isoetes pedersenii H.P. Fuchs (Lycophyta) foi validado para a espécie identificada apenas no Parque Nacional de Mburucuyá, em Corrientes na Argentina. Material preservado em herbário foi avaliado com microscópios estereoscópico, de luz branca e eletrônico de varredura. A espécie foi descrita e tipificada. Um diagnóstico e uma discussão sobre a distribuição e relação com a morfologia de outras espécies de Isoetes são relatados.

Palavras-chave: Argentina, Corrientes, Isoetes, Lycophyta, nova espécie.

\section{REFERENCES}

Arbo MM. 2004. Flórula del Parque Nacional Mburucuyá. In: ACEÑOLAZA FG (Ed), Temas de la biodiversidad del Litoral Fluvial Argentino. INSUGEO. Tucumán, Miscelánea 12.

FUCHS-ECKERT HP. 1982. Zur heutigen Kenntnis von Vorkommen und Verbreitung der südamerikanischen IsoëtesArten. Proceedings of the Koninklike Nederlandse Akademie van Wetenschappen, Series C 85: 205-260.

HALL JB. 1971. Observations on Isoetes in Ghana. Bot J Linn Soc 64: 117-139.

Hickey RJ, Macluf CC And TAYlor WC. 2003. A Reevalutation of Isoetes savatieri Franchet in Argentina and Chile. Amer Fern J 93: 126-136.

Holmgren PK, Holmgren NH AND BARnetT LC. 1990. Index Herbariorum, $8^{\text {th }}$ ed., NYBG, New York USA, $693 \mathrm{p}$.

JOHANSEN DA. 1940. Plant microtechnique. McGraw-Hill Book Company, Inc., New York.

KOTT L AND BRITTON DM. 1985. Role of morphological characteristics of leaves and sporangial region in the taxonomy of Isoetes in northeastern North America. Am Fern J 75: 44-55. 
Krapovickas A. 2000. Troels Myndel Pedersen (26.IX. 1916-5.II.2000). Bonplandia 10: 193-196.

Luque R, Sousa HC And Kraus JE. 1996. Métodos de coloração de Roeser (1972) - modificado - E. Kropp (1972), visando a substituição do azul de astra por azul de alcião 8GS ou 8GX. Acta Bot Bras 10: 199-212.

MaCluf C And Ponce M. 2008. Isoetaceae. In: ZuloAGA ET AL. (Eds), Catálogo de las plantas vasculares del Cono Sur (Argentina, Sur de Brasil, Chile, Paraguay y Uruguay) I: Pteridophyta, Gymnospermae y Monocotyledoneae. Monographs in Systematic Botany from the Missouri Botanical Garden 107: 984.

Macluf C, Morbelli MA And Giudice GE. 2006a. Microspore Morphology of Isoetes (Lycophyta) species from Southern South America. Bot Rev 72: 121-134.

Macluf C, Morbelli MA and Giudice GE. 2006b. Microspore Morphology of Isoetes species (Lycophyta) from Southern South America. Part II. TEM analysis of some selected types. Bot Rev (Lancaster) 72: 135-152.

MC NEILl J ET AL. 2007. International Code of Botanical Nomenclature (Vienna Code) adopted by the Seventeenth International Botanical Congress Vienna, Austria, July 2005. In: Gantner Verlag and Ruggell LichtENSTEIN (Eds), Regnum Vegetabile, 146, XVIII, 568 p.
PARKER D. 1943. Comparison of aquatic and terrestrial plants of Isoetes engelmanni in the Mountain Lake, Virginia area. Am Midl Nat 30: 452-455.

PFEIfFER NA. 1922. Monograph of the Isoetaceae. Ann Mo Bot Gard 9: 79-232.

Ponce MM. 1996. Pteridophyta. In: Zuloaga FO AND Morrone O (Eds), Catálogo de las Plantas Vasculares de la República Argentina I: Pteridophyta, Gymnospermae y Angiospermae (Monocotyledoneae). Monographs in Systematic Botany from the Missouri Botanical Garden 60: 1-79.

PRADA C. 1979. Estudio de la anatomía foliar de las especies españolas del género Isoetes L. Lagascalia 9: 107-113.

PRADA C AND Rolleri C. 2003. Caracteres diagnósticos foliares en taxones ibéricos de Isoetes L. (Isoetaceae), Pteridophyta). Anales Jard Bot Madrid 60: 371-386.

TAKAmiYA M, Watanabe M And Ono K. 1997. Biosystematic studies on the genus Isoetes (Isoetaceae) in Japan. IV. Acta Phytotaxon et Geobotánica 48(2): 89-122.

Tryon AF AND Lugardon B. 1991. Spores of the Pteridophyta. Surface, wall structure and diversity based on electron microscope studies. Springer, New York, 648 p. 